\title{
Polyploidization within the Funariaceae - a key principle behind speciation, sporophyte reduction and the high variance of spore diameters?
}

\author{
ANNA K. OSTENDORF ${ }^{1,2, \#, ~ N I C O ~ V A N ~ G E S S E L ~}{ }^{2, \#, ~ Y A R O N ~ M A L K O W S K Y ~}{ }^{1,3}$, MARKO S. SABOVLJEVIC ${ }^{4}$, \\ STEFAN A. RENSING ${ }^{5,6,7}$, ANITA ROTH-NEBELSICK ${ }^{1} \&$ RALF RESKI $^{2,7,8, *}$ \\ ${ }^{1}$ State Museum of Natural History, Rosenstein 1, 70191 Stuttgart, Germany \\ झ"anna.ostendorf@gmx.net; \\ झ" anita.rothnebelsick@smns-bw.de; (1) https://orcid.org/0000-0002-9401-5128 \\ ${ }^{2}$ Plant Biotechnology, Faculty of Biology, University of Freiburg, Schaenzlestrasse 1, 79104 Freiburg, Germany \\ "=nico.vangessel@biologie.uni-freiburg.de; 내ttps://orcid.org/0000-0002-0606-246X \\ ${ }^{3}$ Nees Institute for Biodiversity of Plants, University of Bonn, Meckenheimer Allee 170, 53115 Bonn, Germany \\ झ"ymalkows@uni-bonn.de; \\ ${ }^{4}$ Institute of Botany and Botanical Garden, Faculty of Biology, University of Belgrade, Takovska 43, 11000 Belgrade, Serbia \\ ”marko@bio.bg.ac.rs; - i https://orcid.org/0000-0001-5809-0406 \\ ${ }^{5}$ Plant Cell Biology, Faculty of Biology, University of Marburg, Karl-von-Frisch-Str. 8, 35043 Marburg, Germany \\ ”-stefan.rensing@biologie.uni-marburg.de; (1) https://orcid.org/0000-0002-0225-873X \\ ${ }^{6}$ SYNMIKRO Center for Synthetic Microbiology, University of Marburg, Karl-von-Frisch-Straße 16, 35043 Marburg, Germany \\ ${ }^{7}$ Signalling Research Centres BIOSS and CIBSS, University of Freiburg, Schaenzlestrasse 18, 79104 Freiburg, Germany \\ ${ }^{8}$ Cluster of Excellence livMATs@ FIT-Freiburg Center for Interactive Materials and Bioinspired Technologies, University of Freiburg, \\ Georges-Köhler-Allee 105, 79110 Freiburg, Germany \\ ="ralf.reski@biologie.uni-freiburg.de; ㄴttps://orcid.org/0000-0002-5496-6711 \\ \#Authors contributed equally \\ "Correspondence: "' ralf.reski@biologie.uni-freiburg.de
}

\begin{abstract}
Although being recognized as a major force behind speciation in flowering plants, the evolutionary relevance of genome duplication (polyploidization) remains largely unexplored in mosses. Phylogenetic and-genomic insights from the model organism Physcomitrella patens and closely related species revealed that polyploidization, likely via hybridization (allopolyploidization), gives rise to new species within the Funariaceae. Based on the phylogenetic analysis of the nuclear single copy gene BRK1 combined with the measurement of DNA content by flow cytometry, we identified Entosthodon hungaricus as such an allopolyploid species. Together with Physcomitrium pyriforme, Physcomitrium eurystomum and Physcomitrium collenchymatum, which were identified previously as species that likely arose by hybridization, E. hungaricus represents an additional allopolyploid lineage of a species complex that is characterized by convergent sporophyte reduction and a considerable variance in spore sizes. Based on morphological and cytological data from 18 species, we highlight the potential impact of polyploidization on the size of the spores and on sporophyte architecture.
\end{abstract}

Keywords: convergent evolution, genome duplication, hybridization, mosses, post-duplication diversification, Entosthodon hungaricus, Physcomitrella patens

\section{Introduction}

Exploring the driving forces behind speciation and diversification is one of the major topics in evolutionary biology. The increasing availability of genome sequences provides evidence for a high relevance of genome duplication (polyploidization) during land plant evolution. Analyses of the first sequenced embryophyte genomes revealed that polyploidization is frequent and a key process behind genome evolution, morphological complexity and speciation (Crow \& Wagner 2006, Soltis \& Soltis 2009; Rensing 2014, Van de Peer et al. 2017). Flowering plants are paleopolyploids descending from ancestors that multiplied their genomes through either auto-or allopolyploidy (Jiao et al. 2011, Van de Peer et al. 2017). In autopolyploids, chromosomal sets originate from the same parent, while in allopolyploids chromosomal sets are genetically different, which means these species result from hybridization of species or genetically divergent lineages. 
Genomic signs for polyploidy are present also in mosses (Rensing et al. 2007, Rensing et al. 2013, Beike et al. 2014). By now, allopolyploidization is widely accepted as the main source of polyploid mosses, as reflected by reports of hybrid species from different families, such as Mniaceae (Wyatt et al. 1988, Wyatt et al. 1992, Wyatt and Odrzykoski 1998), Sphagnaceae (Ricca and Shaw 2010, Stenøien et al. 2011), and Pottiaceae (Košnar et al. 2012). The observation that individual polyploid, hybrid species originate recurrently (Soltis \& Soltis 1999) emphasizes the evolutionary role of this process and its impact on sympatric speciation. As hybridization implies the transfer of genetic material between different taxa, an inter-specific hybrid may experience altered reproductive compatibility with its parental species, especially in the case of polyploidization.

The model organism Physcomitrella patens (Hedwig 1801: 20) Bruch \& Schimper (1849: 13) (or Physcomitrium patens (Hedwig 1801: 20) Mitten (1851: 363) as proposed by Beike et al. 2014 and Medina et al. 2019; P. patens in the following) is a polyploid species that underwent two whole-genome duplication events, 27-35 and 40-48 million years ago (Rensing et al. 2007, Rensing et al. 2008, Lang et al. 2018). It evolved from allopolyploid ancestors of the Physcomitrium-Physcomitrella species complex (McDaniel et al. 2010, Beike et al. 2014).

Funariaceae is a moss family of around 200 species (Crum \& Anderson 1955) with considerable diversity in sporophyte architecture. The sporophytes of the different genera range from complex sporophytes on long setae with a diplolepidous-opposite peristome as found in Funaria to cleistocarpous sporophytes as present in P. patens. Many genera of the Funariaceae, like Funaria, Entosthodon and Physcomitrium, are classified according to their typical sporophyte complexity, although phylogenetic analyses showed that these traits are homoplasious (Liu et al. 2012). All members of the family are monoecious and intra-gametophytic self-fertilization may be the predominant mode of sexual reproduction, at least in isolates of $P$. patens (Perroud et al. 2011). Yet, allo-fertilization between nonconspecific gametophytes has been induced in the lab as well as it was observed in natural habitats where different species often grow in close proximity (von Wettstein 1924, Rensing et al. 2013).

Furthermore, Funariaceae show an enormous variety regarding chromosome numbers (as summarized in Fritsch 1991) and DNA content (Beike et al. 2014). The chromosome number of the $P$. patens model strain is $\mathrm{n}=27$ (Reski et al. 1994, Lang et al. 2018) which is higher than the typical number of chromosomes among mosses (Fritsch 1991), due to at least two rounds of ancestral polyploidization. Chromosome numbers of Funariaceae range from $\mathrm{n}=5$ in Funariella curviseta (Schwägrichen 1823: 17) Sérgio (1988: 10) up to $n=56$ in Entosthodon hungaricus (Boros 1924: 73) Loeske (1929: 115) (Györffy 1964). High chromosome numbers can be found in the genus Physcomitrium, like $\mathrm{n}=54$ chromosomes in Physcomitrium immersum Sullivant (1848: 648) (Bryan 1957) or up to $\mathrm{n}=54$ chromosomes in Physcomitrium pyriforme (Hedwig 1801: 38) Bridel (1827: 815) and Physcomitrium eurystomum Sendtner (1841: 142) (Danilkiv 1981). Nuclear DNA content differs threefold when comparing Funaria hygrometrica Hedwig (1801: 172) with Physcomitrium collenchymatum Gier (1955: 330), P. eurystomum or P. pyriforme (Beike et al. 2014).

These diverse chromosome numbers and DNA contents provide evidence for widespread polyploidy within the Funariaceae. In a previous study, P. pyriforme, P. eurystomum and P. collenchymatum, which are species with increased DNA content and chromosome numbers, were identified as allopolyploids from which morphologically reduced taxa like P. patens arose convergently by sporophyte reduction and adaptation to specific habitats (Beike et al. 2014). Adding to this, traits that are directly associated with the mode and effectiveness of dispersal, such as spore size and seta length, might be correlated with alterations in ploidy. Although adaptive pressure on these traits by a specific lifestyle is to be expected, polyploidization might add to this by additionally favouring local recruitment, e.g. after loss of reproductive compatibility to parental species.

In this study, we expanded an earlier data set (Perroud \& Quatrano 2008, Beike et al. 2014) by eight additional species to include some of the most common species of Physcomitrium and related genera Funaria and Entosthodon. Our aim was (1) to test whether E. hungaricus, which is reported to have high chromosome numbers, is another allopolyploid. For determination of the DNA content material from the herbarium was re-grown to establish in vitro cultures for flow cytometry. Furthermore, three additional accessions of $F$. hygrometrica and P. patens were included to (2) test for variability of the nuclear single copy marker BRK1. Morphological and cytological data from all 18 analysed taxa were compiled from the literature to analyse (3) whether allopolyploids share specific morphological traits in contrast to species that show no signs of allopolyploidization, by means of distinct BRK1 homeologs (polyploidizationderived gene copies) and increased DNA content and/or chromosome numbers. 


\section{Material \& Methods}

\section{Taxon sampling and in vitro cultivation}

The specimens originated from different herbaria as well as from in vitro cultures available in the International Moss Stock Center (IMSC, www.moss-stock-center.org). The taxon set comprises 36 vouchers from 18 species. Detailed information about the species, voucher and Genbank identifiers are given in Table S1. The mosses derived from the IMSC were grown under axenic conditions on solid Knop medium $\left(250 \mathrm{mg} / \mathrm{L} \mathrm{KH}_{2} \mathrm{PO}_{4}, 250 \mathrm{mg} / \mathrm{L} \mathrm{KCl}, 250 \mathrm{mg} / \mathrm{L}\right.$ $\mathrm{MgSO}_{4} \times 7 \mathrm{H}_{2} \mathrm{O}, 1000 \mathrm{mg} / \mathrm{L} \mathrm{Ca}\left(\mathrm{NO}_{3}\right)_{2} \times 4 \mathrm{H}_{2} \mathrm{O}, 12.5 \mathrm{mg} / \mathrm{L} \mathrm{FeSO}{ }_{4} \times 7 \mathrm{H}_{2} \mathrm{O}, \mathrm{pH}=5.8$ with $\mathrm{KOH}$; Reski \& Abel 1985) in Petri dishes. In the case of $E$. hungaricus, plant material was either collected from the field prior to in vitro cultivation (Sabovljevic et al. 2012) or mature spores from herbaria samples were transferred to solid Knop medium to establish cultures for flow cytometric measurements (FCM). A BRK1 sequence from Encalypta streptocarpa Hedwig (1801: 62) was used as an outgroup for phylogenetic analyses.

\section{Phenotypic and cytological characterization}

For phenotypic characterization of the sporophyte (capsule position and form, seta lengths, presence of the peristome, presence of the operculum), plant material from herbaria, in vitro culture, or from the field was analysed using a stereomicroscope (Leica Z16 APO, Leica Microsystems GmbH, Wetzlar, Germany) with an integrated CCD camera (Leica DFC 490, Leica Microsystems). To illustrate the sporophytes from F. hygrometrica, E. hungaricus, $P$. collenchymatum and P. patens, several images were combined into one picture using the LAS 3.8 Multifocus software via focus stacking (Leica Microsystems). For these taxa, the size of the spores was also analysed. We compiled additional morphological information for all taxa analysed in this work from the literature (Limpricht 1895, Williams 1901, Roth 1904, Gier 1955, Bartram 1972, Flowers 1973, De Sloover 1975, Crum \& Anderson 1981, Sérgio 1988, Beever et al. 1992, Boros et al. 1993, Sharp et al. 1994, Ahrens 2000, Allen 2002, Frahm \& Frey 2004, McIntosh 2007, Toren 2008, Fedosov et al. 2010). In the case of multiple ranges of lengths or diameters, the minima and maxima of all references were combined into one range. Chromosome numbers as summarized by Fritsch (1991) were used for calculation of the median chromosome number per species. All collected information is available in Table 1.

TABLE 1. Funariaceae morphological and cytological characteristics. The taxon set is listed on the left. Morphological data of sporophyte and spore size is compiled from Allen (2002), Bartram (1972), Beever et al. (1992), Boros et al. (1993), Crum \& Anderson (1981), De Sloover (1975), Fedosov et al. (2010), Flowers (1973), Frahm \& Frey (2004), Gier (1955), Limpricht (1895), McIntosh (2007), Roth (1904), Sérgio (1988), Sharp et al. (1994) and Toren (2008). *The median chromosome number was calculated from the literature compiled by Fritsch (1991). The minimum (min) and maximum (max) chromosome numbers reported for a certain taxon are depicted behind the median chromosome number. **The genome size is indicated as 1C value according to Beike et al. (2014) and as measured in this work for Entosthodon hungaricus. n.a. $=$ not available.

\begin{tabular}{|c|c|c|c|c|c|c|c|c|c|}
\hline Species & $\begin{array}{l}\text { capsule } \\
\text { position }\end{array}$ & $\begin{array}{l}\text { seta } \\
\text { length } \\
(\mathbf{m m})\end{array}$ & $\begin{array}{l}\text { capsule } \\
\text { form }\end{array}$ & operculum & $\begin{array}{l}\text { revoluble } \\
\text { annulus }\end{array}$ & peristome & $\begin{array}{l}\text { spore } \\
\text { size }(\mu \mathrm{m})\end{array}$ & $\begin{array}{l}\text { median } \\
\text { chromosome } \\
\text { number // } \\
\text { min-max* }\end{array}$ & $\begin{array}{l}\text { genome } \\
\text { size } \\
(1 C) * *\end{array}$ \\
\hline $\begin{array}{l}\text { Funaria } \\
\text { flavicans }\end{array}$ & emergent & $8.0-20.0$ & inclined & present & present & double & $18-30$ & 10 & n.a. \\
\hline $\begin{array}{l}\text { Funaria } \\
\text { hygrometrica }\end{array}$ & emergent & $16.0-70.0$ & inclined & present & present & double & $12.5-18.8$ & $28 / / 4-56$ & $0.44 \pm 0.03$ \\
\hline $\begin{array}{l}\text { Funaria } \\
\text { calvescens }\end{array}$ & emergent & $10.0-70.0$ & inclined & present & present & double & $9-15$ & 14 & n.a. \\
\hline $\begin{array}{l}\text { Entosthodon } \\
\text { americanus }\end{array}$ & emergent & $6.0-10.0$ & inclined & present & absent & double & $24-31$ & n.a. & n.a. \\
\hline
\end{tabular}


TABLE 1. (Continued)

\begin{tabular}{|c|c|c|c|c|c|c|c|c|c|}
\hline Species & $\begin{array}{l}\text { capsule } \\
\text { position }\end{array}$ & $\begin{array}{l}\text { seta } \\
\text { length } \\
(\mathrm{mm})\end{array}$ & $\begin{array}{l}\text { capsule } \\
\text { form }\end{array}$ & operculum & $\begin{array}{l}\text { revoluble } \\
\text { annulus }\end{array}$ & peristome & $\begin{array}{l}\text { spore } \\
\text { size }(\mu \mathrm{m})\end{array}$ & $\begin{array}{l}\text { median } \\
\text { chromosome } \\
\text { number // } \\
\text { min-max* }\end{array}$ & $\begin{array}{l}\text { genome } \\
\text { size } \\
(1 \mathrm{C})^{* *}\end{array}$ \\
\hline $\begin{array}{l}\text { Entosthodon } \\
\text { attenuatus }\end{array}$ & emergent & $6.0-14.0$ & erect & present & absent & single & $22-35$ & 28 & n.a. \\
\hline $\begin{array}{l}\text { Entosthodon } \\
\text { bonplandii }\end{array}$ & emergent & $5.0-20.0$ & erect & present & absent & absent & $20-34$ & n.a. & n.a. \\
\hline $\begin{array}{l}\text { Entosthodon } \\
\text { convexus }\end{array}$ & emergent & $10.0-20.0$ & inclined & present & absent & double & $18-25$ & n.a. & n.a. \\
\hline $\begin{array}{l}\text { Entosthodon } \\
\text { hungaricus }\end{array}$ & emergent & $4.0-10.0$ & erect & present & absent & absent & $30-40$ & $54 / / 22-56$ & $1.96 \pm 0.04$ \\
\hline $\begin{array}{l}\text { Entosthodon } \\
\text { muhlenbergii }\end{array}$ & emergent & $5.0-15.0$ & inclined & present & absent & double & $19-30$ & 28 & n.a. \\
\hline $\begin{array}{l}\text { Entosthodon } \\
\text { pulchellus }\end{array}$ & emergent & $5.0-8.0$ & inclined & present & absent & double & $18-25$ & n.a. & n.a. \\
\hline $\begin{array}{l}\text { Physcomitrium } \\
\text { collenchymatum }\end{array}$ & emergent & $2.0-3.0$ & erect & present & absent & absent & 24-37 & n.a. & $1.51 \pm 0.44$ \\
\hline $\begin{array}{l}\text { Physcomitrium } \\
\text { eurystomum }\end{array}$ & emergent & $4.0-7.0$ & erect & present & absent & absent & $32-46$ & $40 / / 9-54$ & $1.27 \pm 0.32$ \\
\hline $\begin{array}{l}\text { Physcomitrium } \\
\text { pyriforme }\end{array}$ & emergent & $3.0-14.0$ & erect & present & absent & absent & $25-50$ & $36 / / 9-54$ & $1.33 \pm 0.42$ \\
\hline $\begin{array}{l}\text { Physcomitrella } \\
\text { magdalenae }\end{array}$ & immersed & 0.25 & erect & absent & absent & absent & $22-29$ & n.a. & 0.92 \\
\hline $\begin{array}{l}\text { Physcomitrella } \\
\text { patens }\end{array}$ & immersed & 0.2 & erect & absent & absent & absent & $24-34$ & $27 / / 14-28$ & $0.96 \pm 0.15$ \\
\hline $\begin{array}{l}\text { Physcomitrella } \\
\text { readeri }\end{array}$ & immersed & 0.2 & erect & absent & absent & absent & $27-42$ & n.a. & $0.96 \pm 0.05$ \\
\hline $\begin{array}{l}\text { Aphanorrhegma } \\
\text { serratum }\end{array}$ & immersed & 0.2 & erect & present & absent & absent & $26-40$ & 27 & 0.9 \\
\hline $\begin{array}{l}\text { Funariella } \\
\text { curviseta }\end{array}$ & immersed & $1.2-3.0$ & inclined & present & absent & absent & $15-24$ & 5 & n.a. \\
\hline
\end{tabular}

\section{DNA extraction}

In the case of herbarium samples, single gametophores were washed and dried overnight in a paper envelope in a screw top jar filled with silica gel (Carl Roth $\mathrm{GmbH}$, Karlsruhe, Germany). The dried moss tissue was disrupted in a Tissue Lyser (Qiagen, Hilden, Germany) for $2 \mathrm{~min}$ at $20 \mathrm{~Hz}$. Genomic DNA was extracted from approximately 5-10 mg dry weight using the Genomic DNA from Plant Kit II (Macherey-Nagel GmbH \& Co. KG, Düren, Germany) following the manufacturer's protocol. In the case of material grown from in vitro culture, fresh material was used for DNA extraction. DNA from up to $50 \mathrm{mg}$ fresh weight was isolated using the cetyltrimethyl ammonium bromide (CTAB) method (Doyle \& Doyle 1990).

\section{Amplification, cloning and sequencing of $B R K 1$}

The nuclear single copy gene BRK1 (P. patens gene ID: Pp3c8_2740V3.1, Lang et al. 2018) was used as a phylogenetic marker. For the amplification of a part of BRK1 the primers BRICK1_for (GTCGGCATTGCTGTACAA) and BRICK1_rev (CTCCAGCTGACGCTCCAG) were used (Beike et al. 2014). In a final reaction volume of $25 \mu \mathrm{L}$, the PCR was set up using $2.5 \mu \mathrm{L} 10 \times$ DreamTaq Green Buffer (Thermo Scientific, St. Leon-Rot, Germany), $2.5 \mu \mathrm{L}$ deoxyribonucleotide triphosphates (dNTPs, $2 \mathrm{mM}$, Thermo Scientific), $0.2 \mu \mathrm{L}$ DreamTaq polymerase ( $5 \mathrm{U} / \mu \mathrm{l}$, Thermo 
Scientific), $0.5 \mu \mathrm{L}$ of each primer $(10 \mathrm{pmol} / \mu \mathrm{L})$ and $1 \mu \mathrm{L}$ genomic DNA. After an initial denaturation at $94{ }^{\circ} \mathrm{C}$ for 5 min, the cycling conditions consisted of a denaturation step of $45 \mathrm{sec}$ at $94{ }^{\circ} \mathrm{C}$, an annealing step at $53{ }^{\circ} \mathrm{C}$ for $1 \mathrm{~min}$ and an elongation step for $1 \mathrm{~min}$ at $72{ }^{\circ} \mathrm{C}$ for $30-33$ cycles. For final elongation, the reaction was incubated at $72^{\circ} \mathrm{C}$ for $5 \mathrm{~min}$. The PCR was controlled via agarose gel electrophoresis. The PCR products were purified using the Nucleo Spin Gel and PCR Clean-up Kit (Macherey-Nagel GmbH \& Co. KG, Düren, Germany) following the manufacturer's protocol. The purified PCR product and both primers were sent to LGC genomics (Berlin, Germany) or to GATC Biotech (Konstanz, Germany) for Sanger sequencing. BRK1 sequences from E. hungaricus showed nucleotide polymorphisms in the electropherogram of the sequenced PCR product, providing evidence for paralogous (probably homeologous) sequences. To analyse the BRK1 homeologs from E. hungaricus, the PCR products were cloned into the pJET1.2/blunt vector (CloneJET PCR Cloning Kit, Thermo Scientific, St. Leon-Roth, Germany) following the manufacturer's instructions. The vector was transfected into chemically competent $E$. coli cells that were grown on ampicillin-containing (Carl Roth GmbH, Karlsruhe, Germany) solid LB-medium for selection. Bacterial colonies were screened via PCR for the insertion of plasmid DNA using the gene-specific primers. Plasmid DNA extraction was done after an overnight incubation in liquid ampicillin-containing LB-medium at $37{ }^{\circ} \mathrm{C}$ using the GeneJET Plasmid Miniprep-Kit (Thermo Scientific). For each accession of E. hungaricus at least three plasmid DNAs from independent bacterial clones were sequenced.

\section{Sequence analysis and phylogenetic reconstructions}

The sequence chromatograms were analysed using Geneious 8.0.5 (Kearse et al. 2012). Each chromatogram was checked for sequence polymorphisms, i.e. overlapping sequence peaks. In the case of polymorphisms, the PCR product was cloned as described above. Consensus sequences were generated from both sequences obtained from Sanger sequencing using the primers BRICK1_for and BRICK1_rev. Multiple sequence alignments were generated with MAFFT (Katoh \& Standley 2013). Phylogenetic trees were calculated with Bayesian Inference (BI) and Maximum Likelihood analyses (ML) as described in Beike et al. (2014). BI was done with MrBayes 3.2.1 (Huelsenbeck \& Ronquist 2001, Ronquist \& Huelsenbeck 2003) using the GTR substitution model with eight gamma distributed rates, two heated chains and a heated chain parameter of 0.2. Two million cycles for the MCMC algorithm with a sampling frequency of 1,000 were applied, until the average standard deviation of split frequencies dropped below 0.01 . The ML analysis was performed with RAxML 7.2.8 using the GTR gamma nucleotide model and a rapid bootstrapping analysis of 1,000 replicates. The phylogenetic tree was visualized with Geneious 8.0.5. The figure was generated using Inkscape (www.inkscape.org).

\section{Character trait mapping and statistical analysis}

The morphological information from the literature was mapped onto the phylogenetic tree for illustration purposes. Character state mapping of the continuous characters spore size and chromosome number (Table 1) was done with Mesquite 3.03 (Maddison \& Maddison 2006) using unordered parsimony tracing. Correlations between continuous traits (spore size, seta length, chromosome number) were calculated with phylogenetically independent contrasts (PIC) (Felsenstein 1985), which is applicable to phylogenetic trees with polytomies (Garland \& Diaz-Uriarte 1999), using the phenotypic diversity analysis module PDAP:PDTREE for Mesquite 3.03 (Midford et al. 2005, Maddison \& Maddison 2006).

\section{Flow cytometric measurements}

Flow cytometric measurements were carried out according to Schween et al. (2003) with modifications to analyse the DNA content of three E. hungaricus accessions in comparison to the DNA content of P. patens. Gametophores were chopped with a razor blade in 4.6 Diamidino-2-Phenylindol (DAPI) buffer $\left(0.107 \mathrm{~g} \mathrm{MgCl}_{2}^{*} 6 \mathrm{H}_{2} \mathrm{O}, 0.5 \mathrm{~g} \mathrm{NaCl}, 1.211\right.$ $\mathrm{g}$ Tris, $0.1 \mathrm{~mL}$ Triton X-100 in $100 \mathrm{~mL}$ water, $1 \mathrm{mg} / \mathrm{L}$ DAPI, $\mathrm{pH} 7.0$ with $\mathrm{HCl}$ ). The remaining plant debris was filtered and the measurements were made on an Aria III cell sorter system (Becton, Dickinson and Company, BD Biosciences, New Jersey, USA). As configuration, a $85 \mu \mathrm{m}$ nozzle was used with a pressure of 45 psi. DAPI was excited with a 405 $\mathrm{nm} 50 \mathrm{~mW}$ diode laser and the emitted signals were collected with a 450/40 band pass filter. To monitor the records, identified positive signals were gated from SSC-/FSC-plot and displayed as counts in a histogram with linear scale. For the record and analysis, the DIVA version 8.0.1 was used. 


\section{Results}

\section{In vitro cultivation and flow cytometry of Entosthodon hungaricus from herbaria material}

In vitro cultivation of $E$. hungaricus from mature spores was possible after six years of herbarium storage. It took between ten days to three weeks until protonema filaments emerged. First gametophores were observed after 45 days. As determined with FCM from these in vitro cultures, the DNA content of E. hungaricus is higher than in $F$. hygrometrica and P. patens. The 1C value is $1.96 \pm 0.05$ (Table S2), while it is $0.96 \pm 0.15$ in P. patens and $0.44 \pm$ 0.03 in F. hygrometrica (Beike et al. 2014). E. hungaricus has the highest DNA content so far recorded within the Funariaceae, even higher than that of P. pyriforme, P. collenchymatum and P. eurystomum (Table 1).

\section{BRK1 sequence analysis shows no variability between different accessions of the same taxon, even if homeologs are present, and identifies $E$. hungaricus as allopolyploid}

We complemented a published set of 20 accessions representing 10 species (Beike et al. 2014) with 16 additional accessions resulting in a total set of 36 accessions covering 18 distinct species of the Funariaceae (Table S1). For all species, the amplified sequence of the nuclear single copy marker gene BRK1 has a length of approximately $600 \mathrm{bp}$ (Figure 1a). Additional accessions of $F$. hygrometrica from Iceland and Germany, and P. patens from Germany were included to test for marker variability within these taxa. Sequence variability was not detected; the BRK1 sequences are $100 \%$ identical in all three accessions of P. patens and F. hygrometrica, respectively. Except for Entosthodon attenuatus (Dickson 1801: 8) Bryhn (1908: 25), where one single nucleotide polymorphism (SNP) within the intron occurs when comparing both accessions, none of the other species showed sequence variability when comparing multiple accessions of the same species.

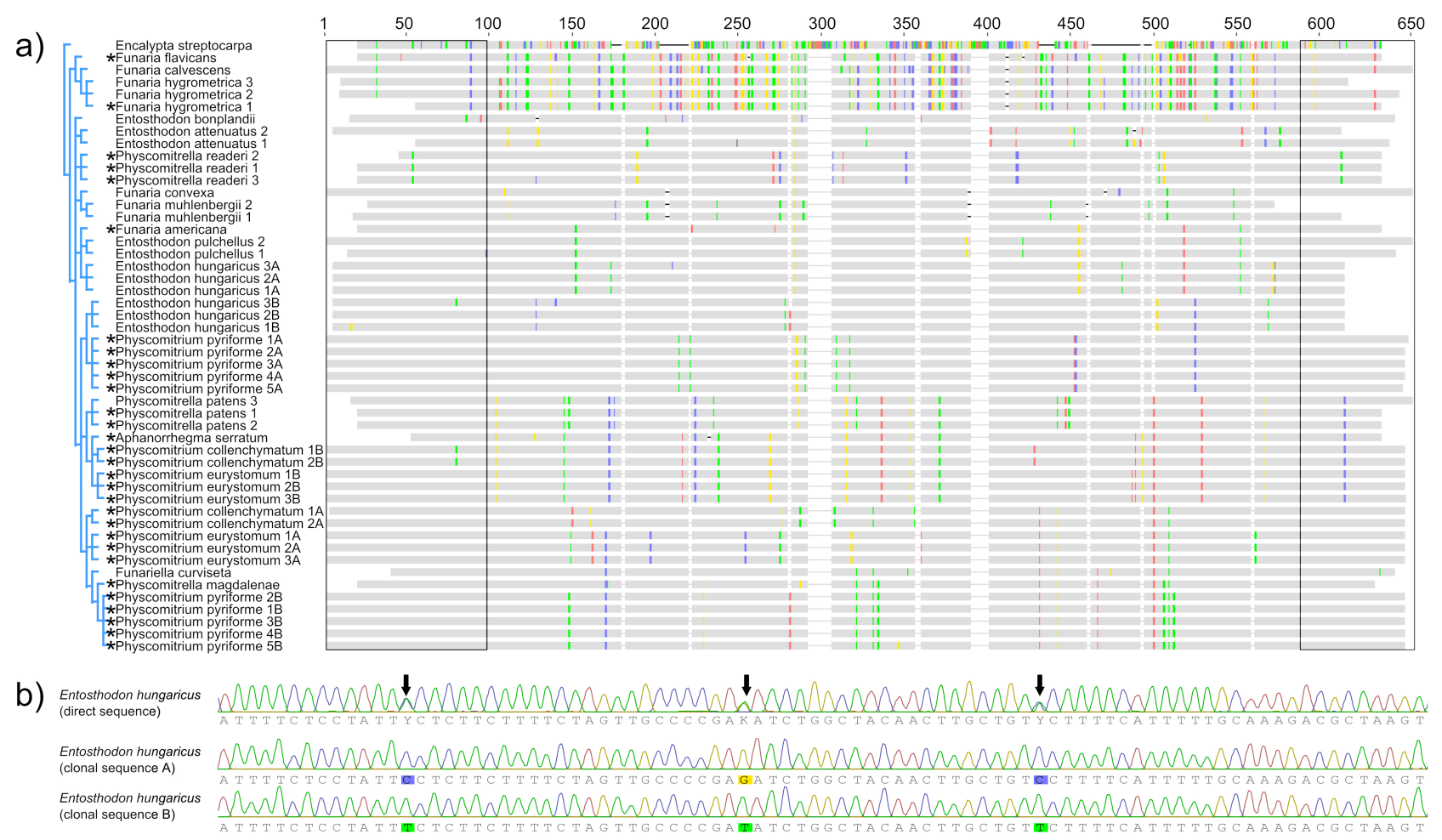

FIGURE 1. Multiple sequence alignment and sequence polymorphisms of BRK1. The nuclear single copy gene BRK1 (P. patens gene ID: Pp3c8_2740V3.1) was amplified and sequenced from 18 Funariaceae. Encalypta streptocarpa (Encalyptaceae) was used as outgroup. (a) Multiple sequence alignment of BRK1. The exon regions flanking the intron are marked in black boxes. Nucleotide positions identical in all species are shown in grey, while nucleotide disagreements are marked with green (T), red (A), blue (C) and yellow (G). The taxa and the Bayesian Inference tree topology are shown on the left. The number of nucleotides is depicted at the top. The sequences previously published by Beike et al. (2014) are highlighted with asterisks. (b) In the BRK1 sequences from all three accessions of Entosthodon hungaricus, identical sequence polymorphisms were detected and highlighted with arrows. The sequences obtained from the cloned PCR products separated two homeologs of BRK1 (clonal sequence A and clonal sequence B). 
As previously shown for P. collenchymatum, P. eurystomum and P. pyriforme (Beike et al. 2014), the BRK1 sequences from E. hungaricus contain SNPs within all three accessions from Germany and Hungary, respectively (Figure 1b). Cloning and sequencing of the corresponding PCR products revealed two distinct BRK1 homeologs (i.e., polyploidization-derived gene copies) in all analysed E. hungaricus accessions (Figure 1b). In all species with multiple BRK1 homeologs more SNPs were observed in the intron than in the exon (Figure 1a). In E. hungaricus no SNPs were observed within the exon, while 14 SNPs were found in the $487 \mathrm{bp}$ intron.

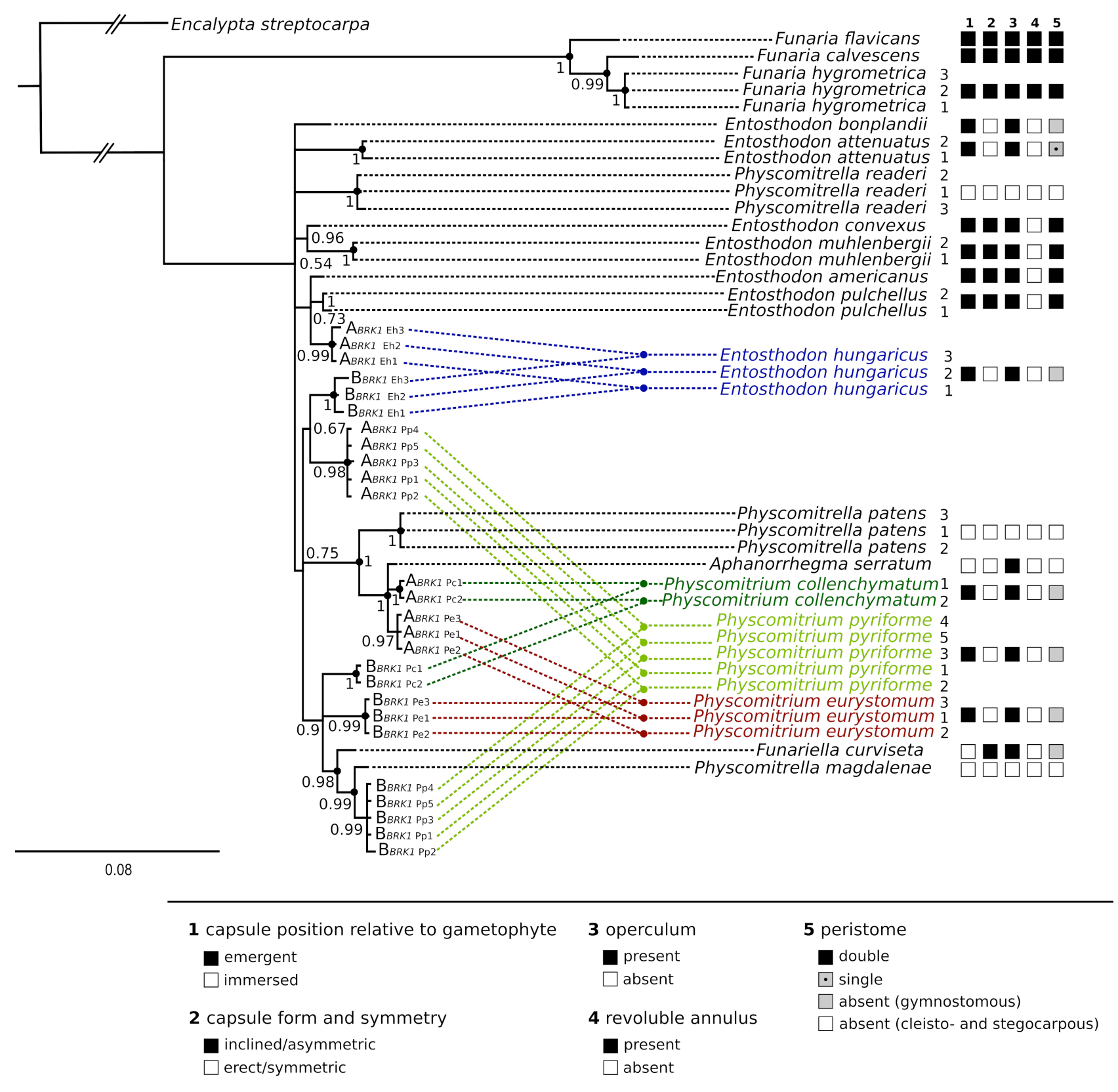

FIGURE 2. Trait mapping of sporophytic traits onto the BRK1-based phylogeny. The phylogenetic tree based on BRK1 sequences was calculated with Bayesian Inference (BI) and Maximum Likelihood (ML). The BI tree is shown in this figure, the support values show posterior probabilities, while nodes with additional ML bootstrap support $>90$ are marked with black dots. The scale bar depicts substitutions per site. BRK1 amplified from Encalypta streptocarpa was used as outgroup. Due to unresolved branching order, the backbone of the major clade is partly shown as multifurcating. Species with two distinct homeologs of BRK1 are shown in blue (Entosthodon hungaricus), dark green (Physcomitrium collenchymatum), light green (Physcomitrium pyriforme) and red (Physcomitrium eurystomum). The two distinct BRK1 homeologs are labelled "A" and "B", followed by the gene name, the initials of the species ("Eh", "Pc", "Pp", "Pe") and the accession numbers (1-5). The branches of the tree are lengthened by dotted lines for graphical representation. Black lines depict species without polymorphisms in the BRK1 sequence; coloured lines depict species with two distinct BRK1 loci. Sporophytic traits are shown on the right; black denotes the characteristics of the type species Funaria hygrometrica. 

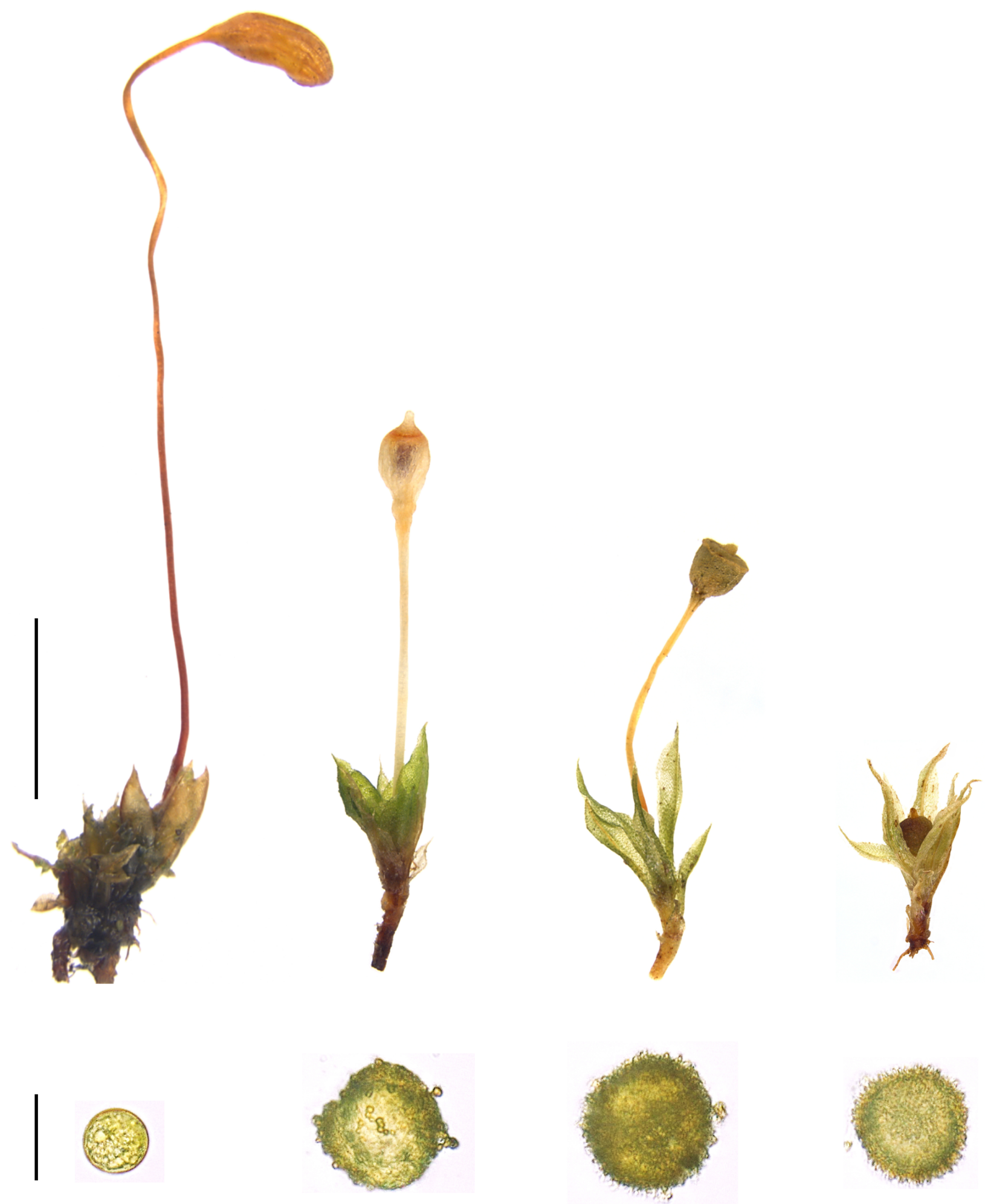

FIGURE 3. Typical Funariaceae sporophytes and spores. Four Funariaceae species are shown, from the left to the right: Funaria hygrometrica, Entosthodon hungaricus, Physcomitrium eurystomum and Physcomitrella patens. The mosses are shown in equal magnification, scale bar $=2.5 \mathrm{~mm}$. The corresponding mature spores are shown below in equal magnification, scale bar $=20 \mu \mathrm{m}$.

The BRK1-phylogeny separates Funaria from an unresolved species complex with diverse sporophyte architecture

Based on phylogenetic analysis of $B R K 1$, two major clades are separated. One clade includes the sequences of Funaria flavicans Michaux (1803: 303), Funaria calvescens Schwägrichen (1816: 77) and F. hygrometrica. The sister 
clade contains sequences of the genera Entosthodon (many species herein are also frequently classified as Funaria), Physcomitrium (including P. patens, Aphanorrhegma serratum (Wilson \& Hooker in Drummond 1841) Sullivant (1848: 647)) and Funariella (Figure 2). In this clade we observe several polytomies, which are also found in multiple gene consensus trees (e.g., McDaniel et al. 2010, Liu et al. 2012) but were resolved in more recent studies (Medina et al. 2018, Medina et al. 2019).

Mapping sporophyte traits onto the BRKl-based phylogeny shows that species from the Funaria-clade share an inclined, emergent sporophyte with operculum, revoluble annulus and completely developed peristome. None of these species shows signs of allopolyploidy by means of multiple BRK1 homeologs (Figure 2).

In the multifurcating clade, sporophyte morphology is highly variable. Entosthodon species have emergent sporophytes with operculum, but are lacking a revoluble annulus. Within the present taxon set all Entosthodon spore capsules are emergent on setae between 4-20 mm, however they are either inclined and asymmetric, or emergent and symmetric (Table 1). Physcomitrium has a gymnostomous, emergent and symmetric spore capsule. The allopolyploids E. hungaricus, P. pyriforme, P. eurystomum and P. collenchymatum share a similar sporophyte complexity, namely an emergent sporophyte with symmetric capsule, operculum, but without a peristome. A noteworthy exception is Entosthodon bonplandii (Hooker 1816) Mitten (1869: 245), which shares a sporophyte complexity but shows no signs for allopolyploidy by means of multiple BRK1 gene copies (Figure 2).

Aphanorrhegma serratum, P. patens and $F$. curviseta have immersed capsules on setae between $0.2-3 \mathrm{~mm}$ (Table 1). While the capsules are emergent and symmetric in A. serratum and P. patens, they are inclined and asymmetric in $F$. curviseta. An operculum is present in A. serratum and F. curviseta, while peristomes and revoluble annuli are lacking in these genera. In none of these taxa multiple $B R K 1$ gene copies were detected.

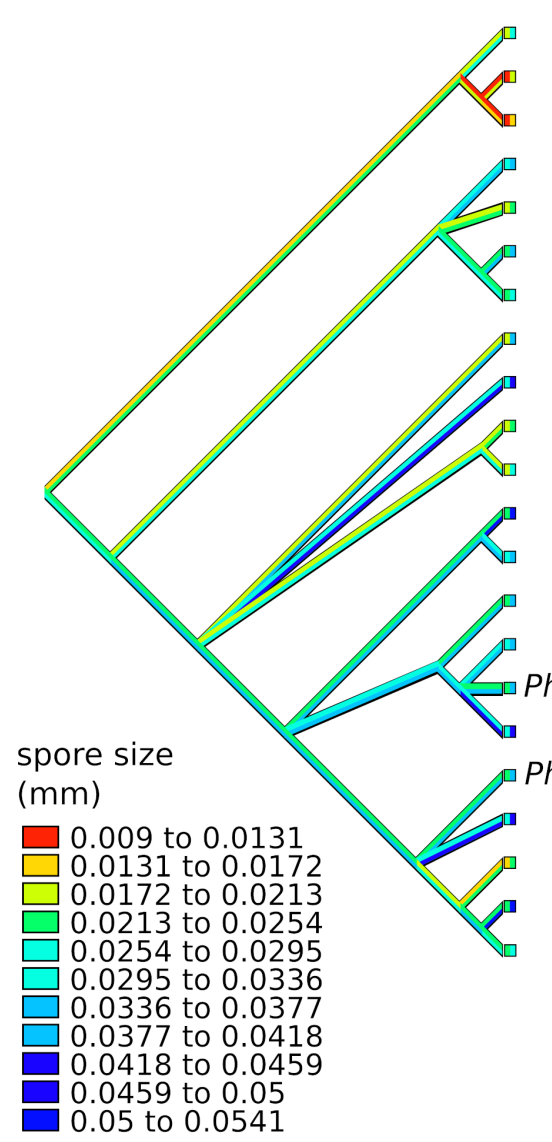

\section{Funaria flavicans \\ Funaria hygrometrica \\ Funaria calvescens}

Entosthodon hungaricus A

Entosthodon pulchellus

Entosthodon attenuatus

Entosthodon americanus

Entosthodon bonplandii

Physcomitrella readeri

Entosthodon convexus

Entosthodon muhlenbergii

Physcomitrium pyriforme A

Entosthodon hungaricus B

Physcomitrella patens

Aphanorrhegma serratum Physcomitrium collenchymatum A

Physcomitrium eurystomum A Physcomitrium collenchymatum B Physcomitrium eurystomum B

Funariella curviseta

Physcomitrium pyriforme B

Physcomitrella magdalenae

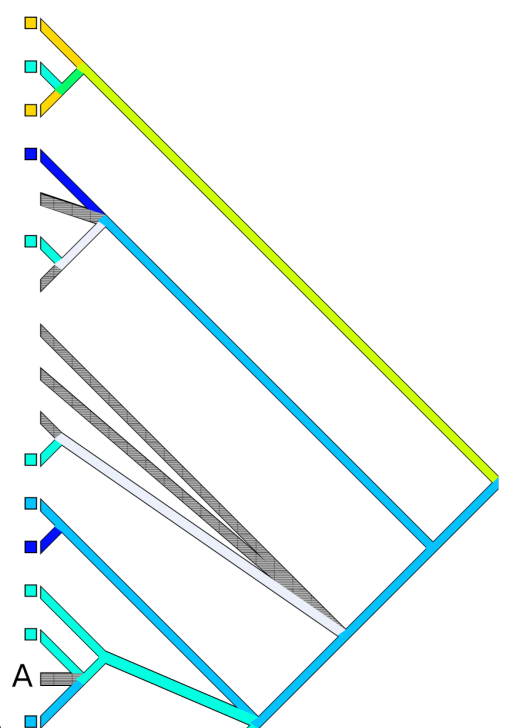

chromosome number (median)

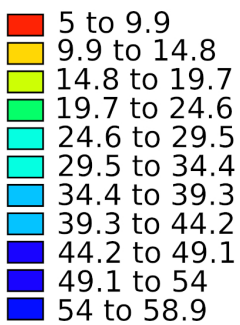

FIGURE 4. Spore size and chromosome numbers mapped onto the BRK1-based phylogeny. The mirrored $B R K 1$-based phylogenetic trees were inferred by Bayesian Inference including only one randomly chosen accession per species. Multiple BRK1 homeologs of the allopolyploid species are labelled "A" and "B". Phylogenetically independent contrasts revealed a positive correlation ( $\mathrm{p}=0.0019$, FDRcorrected $\mathrm{p}=0.0058$ ) between the size of the spores as shown on the left and the median of chromosome counts according to Fritsch (1991) depicted on the right. For species with unknown chromosome numbers, the branches are depicted in grey. 


\section{The size of the spores, but not the length of the seta correlates with the number of chromosomes}

Besides sporophyte architecture, size and ornamentation of spores are quite variable within the Funariaceae (Figure 3). According to the literature, spores from $F$. hygrometrica are 12.5-18.8 $\mu \mathrm{m}$, while chromosome numbers range from $\mathrm{n}=14$ to $\mathrm{n}=28$, and the $1 \mathrm{C}$ value is 0.44 (Table 1 ). In E. hungaricus, spores are more variable with diameters of 30-40 $\mu \mathrm{m}$ (Figure 3), the median chromosome number and DNA content is higher than for example in F. hygrometrica. For $P$. eurystomum, $P$. pyriforme and $P$. collenchymatum we find a comparable situation of large spores along with increased DNA content or chromosome numbers (Table 1). In P. patens, the spores are slightly smaller with 24-34 $\mu \mathrm{m}$ (Figure 3), while the chromosome number is $\mathrm{n}=27$ (Reski et al.1994) and the genome size is $1 \mathrm{C}=0.96$ (Table 1). A possible correlation between spore size and chromosome number becomes even more evident when comparing data from the literature for all Funariaceae included in this work (Table 1). Phylogenetic independent contrast (PIC) analysis based on the $B R K 1$ phylogeny revealed a positive correlation $(\mathrm{p}=0.0019$, FDR-corrected $\mathrm{p}=0.0058)$ between median chromosome number and spore size (Figure 4). In contrast, we did not detect a correlation between chromosome number and the length of the seta.

\section{Discussion}

Based on molecular phylogenetics, it was postulated that Physcomitrium and Physcomitrella under traditional nomenclature are polyphyletic, and that $P$. patens-like, cleistocarpous sporophytes evolved several times convergently from allopolyploid ancestors (McDaniel et al. 2010, Beike et al. 2014). Medina et al. (2018) combined morphological and molecular data for a large Funariaceae taxon set to show that Entosthodon is also polyphyletic and named the evolutionary young, rapidly evolving Entosthodon-Physcomitrium (E-P) species complex. However, in phylogenetic studies based on typically uniparental inherited plastid and mitochondrial markers, the relevance of polyploidy, e.g. based on hybridization, can easily be underestimated. Medina et al. (2019) analysed 648 nuclear loci to infer the evolutionary relationships of five taxa of the Funarioideae. The authors proposed a new monophyletic delineation of Physcomitrium and found P. patens-like (or A. serratum-like) sporophytes to have emerged several times within the Physcomitrium complex, yet they only included haploid accessions in their analyses. We chose to analyse a nuclear single copy gene instead to disclose extant species of hybrid origin based on the presence of both homeologs.

We chose the nuclear single copy gene $B R K 1$ as a marker since it was established in an earlier study within the Funariaceae (Beike et al. 2014) and proved its broad applicability in a molecular fingerprinting of 19 Sphagnum accessions (Heck et al. 2021). In congruence with Medina et al. (2019), our analysis of BRK1 confirms the polyphyly of Entosthodon, Physcomitrium and Physcomitrella under traditional nomenclature, while Funaria forms a monophyletic entity in a sister group position. Additionally, we provide evidence that $E$. hungaricus is a species of hybrid origin, as it has two different homeologs of BRK1 and an increased genome size as compared with other Funariaceae. $E$. hungaricus is a very rare species. Its growth in axenic in vitro culture from herbaria material highlights the potential of such collections for scientific analyses. The regeneration ability of moss spores after long time of dormancy combined with cell culture techniques enables the study of rare, endangered or even extinct species. Moreover, long-time storage over liquid nitrogen has been established (Schulte \& Reski 2004), so that cryopreservation of in-vitro cultures further facilitates preservation of endangered moss species.

E. hungaricus was first recorded as Funaria hungarica Boros (1924: 73) in saline areas in Hungary (Boros 1924). For a long time, it was considered endemic for Europe (Sabovljevic et al. 2012), but more recently it has been recorded at many locations worldwide. Until now, it has been found two times in Germany and at the Neusiedler See in Austria (Zechmeister 2005). Other locations are steppe regions in Europe and Russia as summarized in Pisarenko et al. (2001), Israel (Herrnstadt et al.1991), Central Asia (Pisarenko et al. 2001), the Mediterranean region including Sicily (Cano et al. 1999), Northern Africa (Cano et al. 1999, Ros \& Cano 2008) and the Canary Islands Fuerteventura and Lanzarote (Dirkse et al. 2011). Some of these records are a consequence of taxonomic revisions, in which some taxa were synonymized with E. hungaricus, e.g. Entosthodon maroccanus (Meylan 1937: 426) Hébrard \& Lo Giudice (1997: 145) from Northern Africa (Cano et al. 1999), or Physcomitrium longicolle Trabut (1922) from Northern Africa (Ros \& Cano 2008) and Macaronesia (Dirkse et al. 2011). Based on our work, we postulate allopolyploidy for populations from Germany and Hungary. Whether or not E. hungaricus represents an allopolyploid entity of single origin and worldwide dispersal or whether it is of recurrent origin remains unclear at present.

All allopolyploids detected so far, namely E. hungaricus, P. pyriforme, P. eurystomum and P. collenchymatum, 
share an emergent, symmetric and erect sporophyte with a reduced peristome. A sporophyte like this is the ancestral state in the genus Physcomitrium. A close relationship between E. hungaricus and Physcomitrium was postulated based on the shape of the operculum and the calyptra (Ahrens 1996). Due to this shared sporophytic morphology, polyploidization seems to coincide with this degree of sporophyte complexity. However, the genus Physcomitrium includes both, hybrid taxa with increased chromosome numbers, as for example $P$. immersum with $\mathrm{n}=54$ chromosomes (Bryan 1957), and taxa with smaller chromosome numbers, such as Physcomitrium sphaericum (C. Ludwig 1810: 26) Bridel (1827: 815) or Physcomitrium japonicum (Hedwig 1801: 34) Mitten (1891: 164) with 26 or even less chromosomes (Fritsch 1991), which is rather comparable to P. patens with 27 chromosomes (Reski et al. 1994). According to our work, the length of the seta is not correlated with the median chromosome number. Furthermore, $E$. bonplandii, which also has a sporophyte complexity comparable to Physcomitrium, has only one BRK1 copy, which is proposedly a consequence of haploidization, i.e. gene loss after polyploidization. Only the relatively recent polyploids contain two BRK1 homeologs. In consequence, genome size and chromosome number do not always seem to be in alignment with sporophyte complexity.

In contrast to this, the size of the spores correlates with the chromosome number. According to Crawford et al. (2009), spore sizes and chromosome numbers in mosses are correlated with the sexual system, i.e. mosses with separate sexes have smaller spores, while monoicous mosses, like the Funariaceae, tend to have higher chromosome numbers. Although in many plants polyploids have larger diaspores, a correlation like this was not reported for mosses in general (Crawford et al. 2009). Here, we provide evidence that spore size is correlated with chromosome numbers in the 18 Funariaceae analysed in this study. Interestingly, the bigger spore sizes probably hinder dispersal by wind, and might lead to adaptation to peculiar niches and modes of dispersal. Alternatively, adaptation to open, often disturbed habitats and a short annual lifestyle might select bigger spore sizes to ensure regular, local re-emergence after disturbance (During 1979). For P. patens, it has been hypothesized that spore capsules remain in the muddy ground and are distributed by migratory birds (Beike et al. 2014), a mode of dispersal that has been proven for bryophyte diaspores (Lewis et al. 2014).

All taxa with stego-or cleistocarpous sporophytes, like F. curviseta, Physcomitrella (sensu lato) or A. serratum, contain only one BRK1 copy. P. patens is in fact a polyploid species that underwent two whole-genome duplication events (Rensing et al. 2007, 2008, Lang et al. 2018). Because duplicated chromosomal regions are either retained or lost after duplication (Rensing 2014, Van de Peer et al. 2017), the lack of multiple BRKl homeologs can obviously not rule out an allopolyploid origin of a species. Alternatively, identical homeologs of a single marker might also conceal signs of polyploidization. The E-P species complex evolved during the last 28 million years (Medina et al. 2018). The two whole-genome duplications found in the P. patens genome were dated to 27-35 and 40-48 Mya (Lang et al. 2018). Transcriptome-based analyses of whole genome duplication events suggest that Physcomitrium and Encalypta share both events with P. patens (Lang et al. 2018). Whether and which of the whole genome duplication events visible in the P. patens genome are shared by all members of the E-P species complex requires genome-wide analyses from a broad taxon set. Genome duplication followed by the reduction of chromosomal regions is a key evolutionary principle, probably also applicable to Entosthodon, Physcomitrium and Physcomitrella (and other cleisto-or stegocarpous taxa). Hence, progressive reduction of Funariaceae sporophyte complexity likely results from genomic and morphological reduction after polyploidization.

\section{Acknowledgments}

Funding by German Research Foundation (DFG) via CRC-TRR 141 "Biological Design and Integrative StructuresAnalysis, Simulation and Implementation in Architecture", project B02 (to RR and AR-N) and from the Excellence Initiative of the German Federal and State Governments (EXC 294 to RR) is gratefully acknowledged. We thank all collectors of Funariaceae samples (Table S1) for kindly providing plant material for this study, Marco Göttig for technical assistance of the flow cytometric measurements of E. hungaricus, Lisa Schlittenhardt for expert technical assistance and Anne Katrin Prowse for proofreading the manuscript. 


\section{Data Availability Statement}

Nucleic acid sequences are available in Genbank (KY660687, KY660688, KY660689, KY660690, KY660691, KY660692, KY660693, KY660694, KY660695, KY660696, KY660697, KY660698, KY660699, KY660700, KY660701, KY660702, KY660703, KY660704, KY660705).

The remaining data generated or analysed during this study are included in this published article and its supplementary information files (Supplemental Tables S1, S2, S3).

\section{References}

Ahrens, M. (1996) Entosthodon hungaricus in Südwestdeutschland. Herzogia 12: 199-206.

Ahrens, M. (2000) Funariaceae. In: Nebel, M.P. \& Philippi, G. (Wds.) Die Moose Baden-Württembergs, Band 1. Verlag Eugen Ulmer, Stuttgart.

Allen, B. (2002) Moss Flora of Central America Part 2. Missouri Botanical Garden Press, St. Louis, Missouri.

Bartram, E.B. (1972) Mosses of the Philippines. Otto Koeltz Publishers, Koenigstein-Taunus.

Beever, J., Allison, K.W. \& Child, J. (1992) The mosses of New Zealand. University of Otago Press, Dunedin.

Beike, A.K., von Stackelberg, M., Schallenberg-Rüdinger M., Hanke, S.T., Follo, M., Quandt, D., McDaniel, S.F., Reski, R., Tan, B.C. \& Rensing, S.A. (2014) Molecular evidence for convergent evolution and allopolyploid speciation within the PhyscomitriumPhyscomitrella species complex. BMC Evolutionary Biology 14: 158.

https://doi.org/10.1186/1471-2148-14-158

Boros, Á. (1924) Funaria hungarica, nov. spec. Magyar Botanikai Lapok 23: 73-75.

Boros, A., Járai-Komlódi, M., Tóth, Z. \& Nilsson, S. (1993) An atlas of recent European bryophyte spores. Academic Press (Akadémiai Nyomda), Budapest.

Bridel, S.E. (1827) Bryologia universa seu systematica ad novam methodum dispositio, historia et descriptio omnium muscorum frondosorum huscusque cognitorum cum synonymia ex auctoribus probatissimis. J.A. Barth, Leipzig, 848 pp.

Bruch, P., Schimper, W.P. \& Gümbel, W.T. (1849) Bryologia Europaea seu genera muscorum Europaeorum monographice illustrata. E. Schweizerbart, Stuttgart, 108 pp.

Bryan, V.S. (1957) Cytotaxonomic studies in the Ephemeraceae and Funariaceae. The Bryologist 60: 103-126. https://doi.org/10.2307/3240010

Bryhn, N. (1908) Ad cognitionem bryophytorum archipelagi Canariensis. Det Kongelige Norske Videnskabers Selskabs Skrifter 8: 1-36.

Cano, M.J., Ros, R.M., Guerra, J. \& Gonzalez, J. (1999) The identity of Entosthodon hungaricus (Boros) Loeske and E. maroccanus (Meyl.) Hebr. \& Lo Giudice (=Physcomitrium maroccanum Meyl.). Journal of Bryology 21: 67-70.

https://doi.org/10.1179/jbr.1999.21.1.67

Crawford, M., Jesson, L.K. \& Garnock-Jones, P.J. (2009) Correlated evolution of sexual system and life-history traits in mosses. Evolution 63: 1129-1142.

https://doi.org/10.1111/j.1558-5646.2009.00615.x

Crow, K.D. \& Wagner, G.P. (2006) Proceedings of the SMBE Tri-National Young Investigators' Workshop 2005. What is the role of genome duplication in the evolution of complexity and diversity? Molecular Biology and Evolution 23: 887-892. https://doi.org/10.1093/molbev/msj083

Crum, H.A. \& Anderson, L.E. (1955) Taxonomic studies in the Funariaceae. The Bryologist 58: 1-15. https://doi.org/10.2307/3240096

Crum, H.A. \& Anderson, L.E. (1981) Mosses of Eastern North America, Vol. 1. Columbia University Press, New York, 1328 pp.

Danilkiv, I.S. (1981) Chromosome numbers of the leafy mosses from the Kaliningrad region of RSFSR. Ukrainian Botanical Journal 38: 49-53.

De Sloover, J.L. (1975) Note de bryologie africaine III. Physcomitrella magdalenae sp. nov. Bulletin du Jardin botanique national de Belgique / Bulletin van de National Plantentuin van België 45: 131-135.

https://doi.org/10.2307/3667591

Dickson, J.J. (1801) Fasciculus Plantarum Cryptogamicarum Britanniae, 4. G. Nicol, London, pp. 1-28.

Dirkse, G.M. \& Losada-Lima, A. (2011) Additions and amendments to the Moss Flora of the Canary Islands. Cryptogamie, Bryologie 32: $37-41$.

https://doi.org/10.7872/cryb.v32.iss1.2011.037 
Doyle, J.J. \& Doyle, J.L. (1990) Isolation of plant DNA from fresh tissue. Focus 12: 13-15.

Drummond, T. (1841) Musci Americani: Specimens of Mosses and Junger-manniae collected by the late Thomas Drummond in the Southern States of North America, arranged and named by W. Wilson and WJ Hooker, No. 20, Warrington, 180 pp.

During, H. (1979) Life strategies of bryophytes: A preliminary review. Lindbergia 5: 2-18.

Fedosov, V.E., Ignatova, E.A., Ignatov, M.S. \& Doroshina, G.Y. (2010) On the genus Entosthodon (Funariaceae: Musci) in the Caucasus. Arctoa 19: 75-86.

https://doi.org/10.15298/arctoa.19.06

Felsenstein, J. (1985) Phylogenies and the comparative method. The American Naturalist 125: 1-15. https://doi.org/10.1086/284325

Flowers, S. (1973) Mosses: Utah and the West. Brigham Young University Press, Utah.

Frahm, J.P. \& Frey, W. (2004) Moosflora. Verlag Eugen Ulmer, Stuttgart.

Fritsch, R. (1991) Bryophytorum Bibliotheca 40: Index to bryophyte chromosome counts. Schweizerbart Science Publishers, Stuttgart.

Garland, T.Jr. \& Díaz-Uriarte, R. (1999) Polytomies and phylogenetically independent contrasts: examination of the bounded degrees of freedom approach. Systematic Biology 48: 547-558.

https://doi.org/10.1080/106351599260139

Gier, L.G. (1955) Physcomitrium collenchymatum. Transactions of the Kansas Academy of Science 58: 330-333. https://doi.org/10.2307/3626099

Györffy, B. (1964) Chromosome studies on Hungarian mosses. Acta Biologica Academia Scientia Hungarica 15: 26-27.

Hébrard, J.P. \& Lo Giudice, R. (1997) Entosthodon maroccanus (Meylan) Hébrard et Lo Giudice, nouvelle combinaison pour Physcomitrium maroccanum Meylan (Musci, Funariaceae). Bulletin de la société linnéenne de Provence 48: 145-146.

Heck, M.A., Lüth, V.M., van Gessel, N., Krebs, M., Kohl, M., Prager, A., Joosten, H., Decker, E.L. \& Reski, R. (2021) Axenic in vitro cultivation of 19 peat moss (Sphagnum L.) species as a resource for basic biology, biotechnology, and paludiculture. New Phytologist 229: 861-876.

https://doi.org/10.1111/nph.16922

Hedwig, J. (1801) Species Muscorum Frondosorum, descriptae et tabulis aeneis lxxvii coloratis illustratae. J.A. Barth, Leipzig, 325 pp. https://doi.org/10.5962/bhl.title.26

Herrnstadt, I., Heyn, C.C. \& Crosby, M.R. (1991) A checklist of the mosses of Israel. Bryologist 94: 168-178. https://doi.org/10.2307/3243692

Hooker, W.J. (1816) Plantae cryptogamicae quas in plaga orbis novi aequinoctali collegerunt Alexander de Humboldt et Amat. Bonpland. J. Harding, London.

Huelsenbeck, J.P. \& Ronquist, F. (2001) MRBAYES: Bayesian inference of phylogenetic trees. Bioinformatics 17: 754-755. https://doi.org/10.1093/bioinformatics/btg180

Jiao, Y., Wickett, N.J., Ayyampalayam, S., Chanderbali, A.S., Landherr, L., Ralph, P.E., Tomsho, L.P., Hu, Y., Liang, H., Soltis, P.S., Soltis, D.E., Clifton, S.W., Schlarbaum, S.E., Schuster, S.C., Ma, H., Leebens-Mack, J. \& dePamphilis, C.W. (2011) Ancestral polyploidy in seed plants and angiosperms. Nature 473: 97-100.

https://doi.org/10.1038/nature09916

Katoh, K. \& Standley, D.M. (2013) MAFFT multiple sequence alignment software version 7: improvements in performance and usability. Molecular Biology and Evolution 30: 772-780.

https://doi.org/10.1093/molbev/mst010

Kearse, M., Moir, R., Wilson, A., Stones-Havas, S., Cheung, M., Sturrock, S., Buxton, S., Cooper, A., Markowitz, S., Duran, C., Thierer, T., Ashton, B., Meintjes, P. \& Drummond, A. (2012) Geneious Basic: an integrated and extendable desktop software platform for the organization and analysis of sequence data. Bioinformatics 28: 1647-1649.

https://doi.org/10.1093/bioinformatics/bts199

Košnar, J., Herbstová, M., Kolář, F., Koutecký, P. \& Kučera, J. (2012) A case study of intragenomic ITS variation in bryophytes: Assessment of gene flow and role of polyploidy in the origin of European taxa of the Tortula muralis (Musci: Pottiaceae) complex. Taxon 61: 709-720. https://doi.org/10.1002/tax.614001

Lang, D., Ullrich, K.K., Murat, F., Fuchs, J., Jenkins, J., Haas, F.B., Piednoel, M., Gundlach, H., Van Bel, M., Meyberg, R., Vives, C., Morata, J., Symeonidi, A., Hiss, M., Muchero, W., Kamisugi, Y., Saleh, O., Blanc, G., Decker, E.L., van Gessel, N., Grimwood, J., Hayes, R.D., Graham, S.W., Gunter, L.E., McDaniel, S., Hoernstein, S.N.W., Larsson, A., Li, F.-W., Phillips, J., Ranjan, P., Rokshar, D.S., Rothfels, C.J., Schneider, L., Shu, S., Stevenson, D.W., Thümmler, F., Tillich, M., Villarreal Aguilar, J.C., Widiez, T., Wong, G.K.-S., Wymore, A., Zhang, Y., Zimmer, A.D., Quatrano, R.S., Mayer, K.F.X., Goodstein, D., Casacuberta, J.M., Vandepoele, K., Reski, R., Cuming, A.C., Tuskan, J., Maumus, F., Salse, J., Schmutz, J. \& Rensing, S.A. (2018) The Physcomitrella patens chromosome-scale assembly reveals moss genome structure and evolution. Plant Journal 93: 515-533. 
https://doi.org/10.1111/tpj.13801

Lewis, L.R., Behling, E., Gousse, H., Qian, E., Elphick, C.S., Lamarre, J.F., Bêty, J., Liebezeit, J., Rozzi, R., \& Goffinet, B. (2014) First evidence of bryophyte diaspores in the plumage of transequatorial migrant birds. PeerJ 2: e424. https://doi.org/10.7717/peerj.424

Limpricht, G. (1895) Die Laubmoose Deutschlands, Oesterreichs und der Schweiz. In: Fischer, A., Hauck, F., Limpricht, G., Luerssen, C., Migula, W., Rehm, H., Richter, P. \& Winter, G. (Eds.) Dr. L. Rabenhorst's Kryptogamen-Flora von Deutschland, Oesterreich und der Schweiz. Verlag von Eduard Kummer, Leipzig, 853 pp.

Liu, Y., Budke, J.M. \& Goffinet, B. (2012) Phylogenetic inference rejects sporophyte-based classification of the Funariaceae (Bryophyta): rapid radiation suggests rampant homoplasy in sporophyte evolution. Molecular Phylogenetics and Evolution 62: 130-145. https://doi.org/10.1016/j.ympev.2011.09.010

Loeske, L. (1929) Die Laubmoose Europas II. Funariaceae. Repertorium Specierum Novarum Regni Vegetabilis, Sonderbeiheft B 3 (2): $1-171$.

Ludwig, C. (1810) Deutschlands kryptogamische Gewächse oder die 24. Classe des Linné schen Systems, 2. Band, C. Schkuhr, Wittenberg, $212 \mathrm{pp}$.

Maddison, W.P. \& Maddison, D.R. (2006) Mesquite: A modular system for evolutionary analysis. Version 1.1. [http://mesquiteproject. org]

McDaniel, S.F., von Stackelberg, M., Richardt, S., Quatrano, R.S., Reski, R. \& Rensing, S.A. (2010) The speciation history of the Physcomitrium-Physcomitrella species complex. Evolution 64: 217-231.

https://doi.org/10.1111/j.1558-5646.2009.00797.x

McIntosh, T.T. (2007) Funariaceae Schwägrichen. In: Crosby, M.R., Delgadillo, M.C., Harris, H., Hill, M., Kiger, R.W., McIntosh, T., Murray, B.M., Reese, W.D., Stark, L.R., Thiers, B., Vitt, D.H., Yatskievych, K. , Zander, R.H. \& Zarucchi, J.L. (Eds.) Flora of North America: Volume 27: Bryophytes: Mosses, Part 1. Oxford University Press, New York.

Medina, R., Johnson, M., Liu, Y., Wilding, N., Hedderson, T.A., Wickett, N. \& Goffinet, B. (2018) Evolutionary dynamism in bryophytes: Phylogenomic inferences confirm rapid radiation in the moss family Funariaceae. Molecular Phylogenetics and Evolution 120: 240-247.

https://doi.org/10.1016/j.ympev.2017.12.002

Medina, R., Johnson, M.G., Liu, Y., Wickett, N.J., Shaw, A.J. \& Goffinet, B. (2019) Phylogenomic delineation of Physcomitrium (Bryophyta: Funariaceae) based on targeted sequencing of nuclear exons and their flanking regions rejects the retention of Physcomitrella, Physcomitridium and Aphanorrhegma. Journal of Systematics and Evolution 57: 404-417. https://doi.org/10.1111/jse.12516

Meylan, C. (1937) Note sur une nouvelle espèce de Physcomitrium. Bulletin de la Société d'Histoire Naturelle de l'Afrique du Nord 28: $426-427$.

Michaux, A. (1803) Flora Boreali-Americana, sistens caracteres plantarum quas in America septentrionali collegit et detexit Andreas Michaux, Tomus Secundus. Fratres Levrault, Paris/ Strasbourg, 340 pp. https://doi.org/10.5962/bhl.title.50919

Midford, P.E., Garland, T.Jr. \& Maddison, W.P. (2005) PDAP Package of Mesquite. Version 1.07.

Mitten, W. (1851) A list of all the Mosses and Hepaticae hitherto observed in Sussex. Annals and Magazine of Natural History, series 2 , 8: $362-370$ https://doi.org/10.1080/03745486109494987

Mitten, W. (1869) Musci Austro-Americani. Journal of the Linnean Society, Botany 12: 1-632. https://doi.org/10.1111/j.1095-8339.1871.tb00633.x

Mitten, W. (1891) An Enumeration of all the Species of Musci and Hepaticae recorded from Japan. Transactions of the Linnean Society of London, 2nd series, Botany 3: 153-206. https://doi.org/10.1111/j.1095-8339.1891.tb00626.x

Perroud, P.F. \& Quatrano, R.S. (2008) BRICK1 is required for apical cell growth in filaments of the moss Physcomitrella patens but not for gametophore morphology. Plant Cell 20: 411-422.

https://doi.org/10.1105/tpc.107.053256

Perroud, P.F., Cove, D.J., Quatrano, R.S., McDaniel, S.F. (2011) An experimental method to facilitate the identification of hybrid sporophytes in the moss Physcomitrella patens using fluorescent tagged lines. New Phytologist 191: 301-306. https://doi.org/10.1111/j.1469-8137.2011.03668.x

Pisarenko, O.Y., Ignatova, E.A. \& Ignatov, M.S. (2001) Entosthodon hungaricus (Boros) Loeske (Funariaceae, Musci) in Altaisky Territory, South Siberia. Arctoa 10: 97-102.

https://doi.org/10.15298/arctoa.10.10

Rensing, S.A., Ick, J., Fawcett, J.A., Lang, D., Zimmer, A.D., Van de Peer, Y. \& Reski, R. (2007) An ancient genome duplication contributed 
to the abundance of metabolic genes in the moss Physcomitrella patens. BMC Evolutionary Biology 7: 130.

https://doi.org/10.1186/1471-2148-7-130

Rensing, S.A., Lang, D., Zimmer, A.D., Terry, A., Salamov, A., Shapiro, H., Nishiyama, T., Perroud, P.F., Lindquist, E.A., Kamisugi, Y., Tanahashi, T., Sakakibara, K., Fujita, T., Oishi, K., Shin-I, T., Kuroki, Y., Toyoda, A., Suzuki, Y., Hashimoto, S., Yamaguchi, K., Sugano, S., Kohara, Y., Fujiyama, A., Anterola, A., Aoki, S., Ashton, N., Barbazuk, W.B., Barker, E., Bennetzen, J.L., Blankenship, R., Cho, S.H., Dutcher, S.K., Estelle, M., Fawcett, J.A., Gundlach, H., Hanada, K., Heyl, A., Hicks, K.A., Hughes, J., Lohr, M., Mayer, K., Melkozernov, A., Murata, T., Nelson, D.R., Pils, B., Prigge, M., Reiss, B., Renner, T., Rombauts, S., Rushton, P.J., Sanderfoot, A., Schween, G., Shiu, S.H., Stueber, K., Theodoulou, F.L., Tu, H., Van de Peer, Y., Verrier, P.J., Waters, E., Wood, A., Yang, L., Cove, D., Cuming, A.C., Hasebe, M., Lucas, S., Mishler, B.D., Reski, R., Grigoriev, I.V., Quatrano, R.S. \& Boore, J.L. (2008) The Physcomitrella genome reveals evolutionary insights into the conquest of land by plants. Science 319: 64-69. https://doi.org/10.1126/science.1150646

Rensing, S.A., Beike, A.K. \& Lang, D. (2013) Evolutionary importance of generative polyploidy for genome evolution of haploiddominant land plants. In: Leitch, I.J., Greilhuber, J., Dolezel, J. \& Wendel, J. (Eds.) Plant Genome Diversity Volume 2, Springer, Vienna, $356 \mathrm{pp}$. https://doi.org/10.1007/978-3-7091-1160-4_18

Rensing, S.A. (2014) Gene duplication as a driver of plant morphogenetic evolution. Current Opinion in Plant Biology 17: 43-48. https://doi.org/10.1016/j.pbi.2013.11.002

Reski, R. \& Abel, W.O. (1985) Induction of budding on chloronemata and caulonemata of the moss, Physcomitrella patens, using isopentenyladenine. Planta 165: 354-358. https://doi.org/10.1007/BF00392232

Reski, R., Faust, M., Wang, X.H., Wehe, M. \& Abel, W.O. (1994) Genome analysis of the moss Physcomitrella patens (Hedw.) B.S.G.. Molecular \& General Genetics 244: 352-359. https://doi.org/10.1007/BF00286686

Ricca, M., Shaw, A.J. (2010) Allopolyploidy and homoploid hybridization in the Sphagnum subsecundum complex (Sphagnaceae: Bryophyta). Biological Journal of the Linnean Society 99: 135-151. https://doi.org/10.1111/j.1095-8312.2009.01340.x

Ronquist, F. \& Huelsenbeck, J.P. (2003) MrBayes 3: Bayesian phylogenetic inference under mixed models. Bioinformatics 19: 15721574 . https://doi.org/10.1093/bioinformatics/btg180

Ros, R.M. \& Cano, M.J. (2008) Identity of North African endemic bryophytes, 2. Cryptogamie, Bryologie 29: $135-141$.

Roth, G. (1904) Die europäischen Laubmoose. Leipzig, Germany. https://doi.org/10.5962/bhl.title.58319

Sabovljevic, M.S., Papp, B., Sabovljević, A., Vujičić, M., Szurdoki, E. \& Segarra-Moragues, J.G. (2012) In vitro micropropagation of rare and endangered moss Entosthodon hungaricus (Funariaceae). Bioscience Journal 28: 632-640.

Schwägrichen, C.F. (1816) Species Muscorum Frondosorum, descriptae et tabulis aeneis lxxvii coloratis illustratae, Supplementum Primum. J.A. Barth, Leipzig, pp. 1-373.

Schwägrichen, C.F. (1823) Species Muscorum Frondosorum, descriptae et tabulis aeneis lxxvii coloratis illustratae, Supplementum Secundum. J.A. Barth, Leipzig, pp. 1-86.

Sérgio, C. (1988) Morphological, karyological and phytogeographic observations on Entosthodon curvisetus (Schwager.) C. Müll. as a basis for a new genus, Funariella Sérgio (Funariaceae: Musci). Orsis: organismes i sistemes 3: 5-13.

Schulte, J. \& Reski, R. (2004) High throughput cryopreservation of 140,000 Physcomitrella patens mutants. Plant Biology 6: $119-127$. https://doi.org/10.1055/s-2004-817796

Schween, G., Gorr, G., Hohe, A. \& Reski, R. (2003) Unique tissue-specific cell cycle in Physcomitrella. Plant Biology 5: 50-58. https://doi.org/10.1055/s-2003-37984

Sharp, A.J., Crum, H. \& Eckel, P.M. (1994) The moss flora of Mexico. Part One. The New York Botanical Garden, Bronx, New York, 580 pp.

Sendtner, O. (1841) Musci quidam frondosi recentius detecti. Denkschriften der Bayerischen Botanischen Gesellschaft in Regensburg 3: $138-151$.

Soltis, D.E. \& Soltis, P.S. (1999). Polyploidy: recurrent formation and genome evolution. Trends in Ecology \& Evolution 14: $348-352$. https://doi.org/10.1016/S0169-5347(99)01638-9

Soltis, P.S. \& Soltis, D.E. (2009) The role of hybridization in plant speciation. Annual Review of Plant Biology 60: 561-588. https://doi.org/10.1146/annurev.arplant.043008.092039

Stenøien, H.K., Shaw, A.J., Stengrundet, K. \& Flatberg, K.I. (2011) The narrow endemic Norwegian peat moss Sphagnum troendelagicum originated before the last glacial maximum. Heredity 106: 370-382. 
https://doi.org/10.1038/hdy.2010.96

Sullivant, W. (1848) Musci and hepaticae. In: Gray, A. (Ed.) A Manual of the Botany of the Northern United States. J. Monroe \& Co., Boston, $647 \mathrm{pp}$.

Toren, D. (2008) Funaria convexa Spruce (Musci: Funariaceae) new to North America. Evansia 25: 94-96.

https://doi.org/10.1639/0747-9859-25.4.94

Trabut, L.C. (1922) Deux Funariacées nouvelles. Revue Bryologique 49: 64-65.

Van de Peer, Y., Mizrachi, E. \& Marchal, K. (2017) The evolutionary significance of polyploidy. Nature Review Genetics 18: 411-424. https://doi.org/10.1038/nrg.2017.26

Von Wettstein, F. (1924) Morphologie und Physiologie des Formwechsels der Moose auf genetischer Grundlage I. Zeitschrift für induktive Abstammungs-und Vererbungslehre 33: 1-236.

https://doi.org/10.1007/BF01762372

Williams, R. (1901) Funaria flavicans Michx. The Bryologist 4: 9-10. https://doi.org/10.2307/3238874

Wyatt, R., Odrzykoski, I.J., Stoneburner, A., Bass, H.W. \& Galau, G.A. (1988) Allopolyploidy in bryophytes: Multiple origins of Plagiomnium medium. Proceedings of the National Academy of Sciences of the United States of America 85: 5601-5604. https://doi.org/10.1073/pnas.85.15.5601

Wyatt, R., Odrzykoski, I.J. \& Stoneburner, A. (1992) Isozyme evidence of reticulate evolution in mosses: Plagiomnium medium is an allopolyploid of P. ellipticum $\times$ P. insigne. Systematic Botany 17: 532-550.

https://doi.org/10.2307/2419725

Wyatt, R. \& Odrzykoski, I.J. (1998) On the origins of the allopolyploid moss Plagiomnium cuspidatum. Bryologist 101: $263-271$. https://doi.org/10.2307/3244203

Zechmeister, H.G. (2005) Bryophytes of continental salt meadows in Austria. Journal of Bryology 27: 297-302.

https://doi.org/10.1179/174328205X71442

SUPPLEMENTAL TABLE S1. Taxon Set

SUPPLEMENTAL TABLE S2. Flow cytometry of Entosthodon hungaricus in comparison to Physcomitrella patens

SUPPLEMENTAL TABLE S3. Phylogenetic independent contrasts calculated from the continuous characters seta length, spore size and chromosome number 